\title{
PAPILLARY LYMPHOID HYPERPLASIA AT THE ILEOCAECAL VALVE AS A CAUSE OF ACUTE INTUSSUSCEPTION IN INFANCY
}

\author{
BY \\ J. S. CORNES* and I. M. P. DAWSON \\ From the Vincent Square Laboratories, Westminster Medical School, London
}

(RECEIVED FOR PUBLICATION SEPTEMBER 10, 1962)

\begin{abstract}
Although hyperplasia of lymphoid tissue at the ileocaecal valve and in the terminal ileum has been frequently suggested as a possible cause of acute intussusception in infancy and early childhood (Walton, 1911; Perrin and Lindsay, 1921-1922; Wakeley and Atkinson, 1938), very few cases have been reported in the literature. Evidence for this condition is therefore difficult to obtain. Surgical specimens are rarely available for examination and when they are the intestine is often necrotic and the primary lesion obscure. This report illustrates a case occurring in a 7-month-old male infant treated by surgical resection. The specimen was available for examination, and the pathology was fortunately well preserved.
\end{abstract}

\section{Case Report}

First Admission. A male, born on February 14, 1954, was admitted to the Westminster Children's Hospital as an acute abdominal emergency on October 2, 1954. He began to vomit, draw up his legs and scream 18 hours before admission. He passed several motions consisting of blood and slime. Between attacks he lay quiet and still. He had been previously in good health. He was breast fed, and his mother had just begun to wean him.

On examination he appeared a pale, well-nourished baby. A clearly-defined sausage-shaped mass could be felt in the left hypochondrium. On rectal examination the mass was just palpable at the tip of the finger.

A laparotomy was performed and an intussusception was found in the descending colon. When the intussusception was reduced, the terminal ileum that had formed its apex appeared to be visible. No cause for the intussusception was found.

He made a good post-operative recovery, was discharyed from hospital after six days, and remained in good health for the next five weeks.

Second Admission. On Novemter 11, 1954, he was readmitted as an acute atdominal emergency. Three

- Present address : Department of Pathology, University of Bristol. hours before admission he had attacks of screaming and vomiting. Between attacks he lay quiet and still. His bowel motions had been normal.

On examination he appeared a pale, well-nourished infant, screaming with pain. Visible peristalsis was present in the atdomen, bowel sounds were increased, and a mass was palpable in the left hypochondrium. No mass could be felt by rectal examination, but bloodstained mucus appeared on the finger-stall.

A laparotomy was performed and an ileocolic intussusception was found. After reduction a soft sessile tumour could be felt at the ileocaecal valve. The terminal ileum was opened and a tumour was found at this site which was thought to be a papilloma. The terminal ileum, caecum, appendix, and part of the ascending colon were removed, and the ileum joined to the ascending colon by an end-to-side anastomosis.

He made a slow but gradual recovery from this operation and was discharged from hospital one month after admission. Three days after the second operation his haemoglobin was $9.9 \mathrm{~g} . / 100 \mathrm{ml} .\left(68^{\circ} \%\right)$, and his white blood cells $14,800 /$ c.mm.: polymorphs $36^{\circ} \%$ : lymphocytes $61 \%$; eosinophils $3 \%$. When seen a month laier he was in good health and gaining weight. A barium meal with follow-through examination revealed no further abnormality in the gastro-intestinal tract.

Patholozy. The specimen consisted of $4.5 \mathrm{~cm}$. of terminal ileum, ileocaecal valve, appendix, caecum, and approximately $1 \mathrm{~cm}$. of ascending colon. A large sessile papillary tumour, $3 \mathrm{~cm}$. in diameter. surrounded the ileocaecal valve (Fig. 1). The remainder of the terminal ileum, caecum, ascending colon and appendix appeared normal. The mesenteric lymph nodes were not enlarged.

Sections from the appendix and mesenteric lymph nodes showed no abnormality. Sections from the papillary tumour at the ileocaecal valve showed a marked follicular lymphoid hyperplasia completely filling the submucosa. The muscle coats were not involved, but the mucosal surface was elevated and thrown into tall, slender papillae (Fig. 2). The mucosa was stretched and distorted by this lymphoid tissue, and small areas of mucosal erosion and ulceration could be seen. 


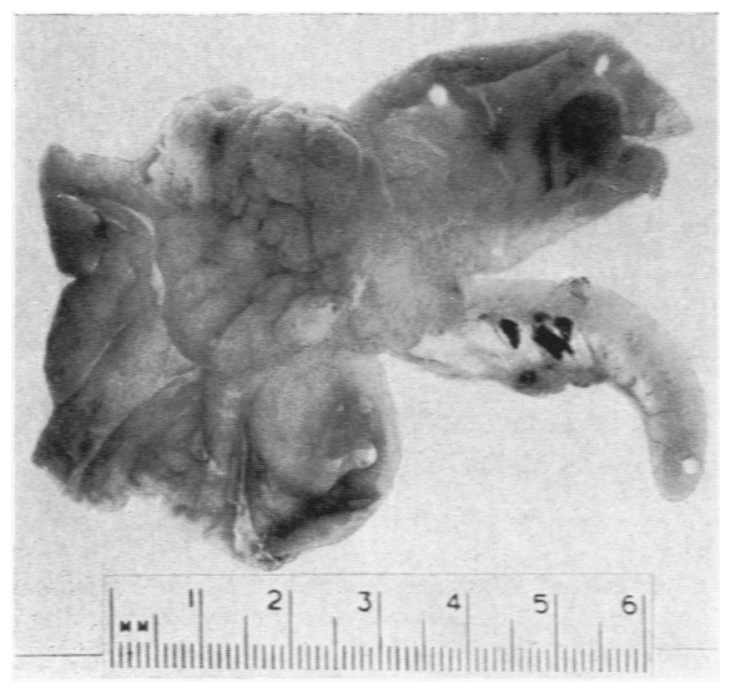

FKG. 1.-Papillary tumour at ileocaecal valve.

\section{Discussion}

Data from 13 recorded cases of patients with ileocaecal lymphoid hyperplasia requiring surgical intervention are summarized in the Table. Nine of the 13 patients had acute intussusception, and six of these patients had recurrence of the intussusception after a simple reduction had been carried out. Eight patients had haemorrhage into the small or large intestine attributed to ulceration or erosion of the mucosa. The cause of the lymphoid hyperplasia was not determined in any of the reported cases. There was no history of upper respiratory tract infection or of gastro-enteritis, and no evidence of mesenteric lymphadenitis at operation.

Any reasonable explanation for the cause of acute intussusception in infancy and early childhood must account for the type of patient concerned, the apparent lack of any precipitating factor, and the site of the intussusception.

It is generally agreed that babies with intussusception have a well-nourished and healthy appearance, and that intussusception is rare in a child who is thin, undernourished and poorly developed (Morrison and Court, 1948; Gross, 1953). Czerney (1907) was one of the first to notice that overweight children had prominent lymphoid tissue, and that this tissue could be reduced by dietetic treatment. These observations suggest that children with intussusception may have prominent lymphoid tissue in their gastro-intestinal tract.

In approximately $90 \%$ of cases, intussusception starts at the ileocaecal valve or in the lower end of

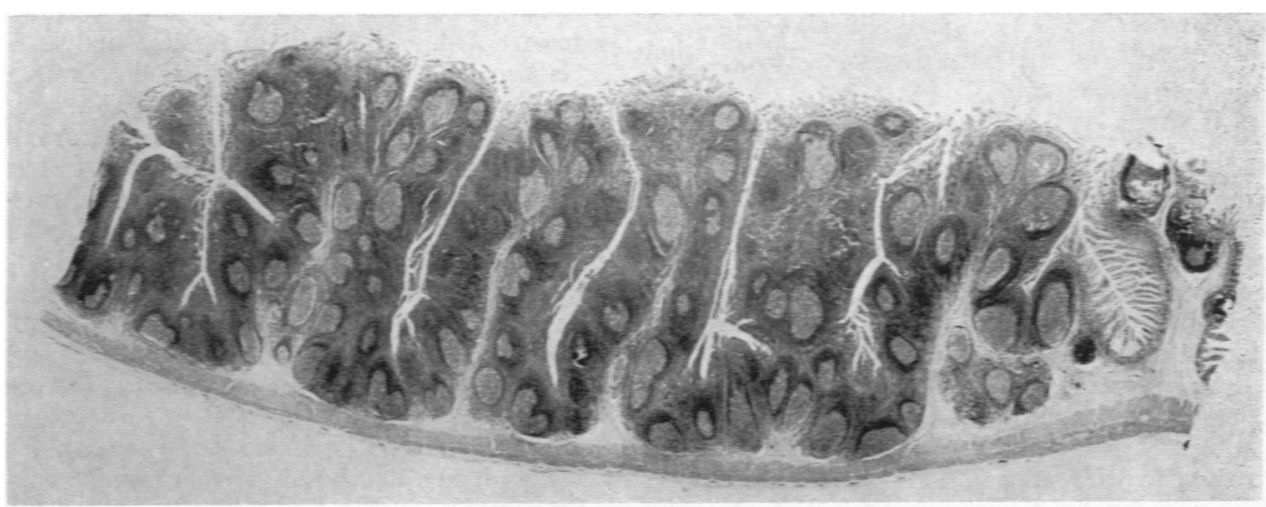

FiG. 2.- Section of ileocaecal valve. showing follicular lymphoid hyperplasia with papillary pattern of the overlying mucosa. (Haematoxylin and cosin $\times 6$.)

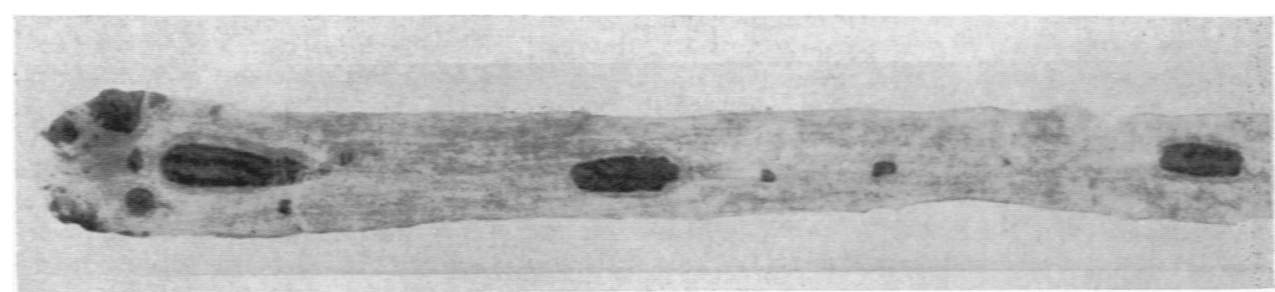

Fig. 3.-Small intestine from make infant aged 7 weeks, showing distribution of Peyer's patches in the terminal ileum (centre) and around the ileocaecal valve (left). Nuclear fixation with dilute acetic acid. Transillumination. 
TABLE

DATA IN RECORDED CASES OF ILEOCAECAL LYMPHOID HYPERPLASIA REQUIRING SURGICAL INTERVENTION

\begin{tabular}{|c|c|c|c|c|c|c|c|c|c|}
\hline \multirow{2}{*}{\multicolumn{4}{|c|}{ Reference }} & \multicolumn{2}{|c|}{ Patient } & \multicolumn{2}{|c|}{ Symptoms } & \multicolumn{2}{|c|}{ Operations } \\
\hline & & & & \multirow{2}{*}{$\frac{\text { Sex }}{M}$} & \multirow{2}{*}{$\begin{array}{l}\text { Age } \\
5 \text { mths }\end{array}$} & \multirow{2}{*}{$\frac{\text { Obstruction }}{\text { Yes }}$} & \multirow{2}{*}{$\begin{array}{l}\text { Haemorrhage } \\
\text { Minimal }\end{array}$} & \multirow{2}{*}{$\frac{\text { First }}{\text { Reduction }}$} & \multirow{2}{*}{$\begin{array}{c}\text { Second } \\
\text { Resection }\end{array}$} \\
\hline Stout (1927) & . & . & . & & & & & & \\
\hline $\begin{array}{l}\text { Dennis (1947) } \\
\text { O'Sullivan and Child (195 }\end{array}$ & $\cdots$ & $\cdots$ & $\begin{array}{l}\cdots \\
\cdots\end{array}$ & $\begin{array}{l}\mathbf{M} \\
\mathbf{M} \\
\mathbf{F} \\
\mathbf{M}\end{array}$ & $\begin{array}{l}3 \text { yrs } \\
3 \text { yrs } \\
11 \text { mths } \\
4 \text { yrs }\end{array}$ & $\begin{array}{l}\text { Yes } \\
\text { Yes } \\
\text { Yes } \\
\text { Yes }\end{array}$ & $\begin{array}{l}\text { None } \\
\text { None } \\
\text { Moderate } \\
\text { None }\end{array}$ & $\begin{array}{l}\text { Reduction } \\
\text { Reduction } \\
\text { Resection } \\
\text { Resection }\end{array}$ & $\begin{array}{l}\text { Resection } \\
\text { Resection } \\
-\end{array}$ \\
\hline \multicolumn{3}{|c|}{ Sarason, Prior and Prowda (1955) } & . & $\mathbf{M}$ & 4 mths & Yes & Minimal & Reduction & Reduction \\
\hline \multicolumn{3}{|c|}{ Roviralta and Roca De Vinals (1958) } & . & $\mathbf{F}$ & $4 \mathrm{mths}$ & Yes & Moderate & Resection & - \\
\hline Cooke and Lewis (1960) & . & . & . & $\mathbf{M}$ & $10 \mathrm{mths}$ & Yes & $?$ & Reduction & - \\
\hline \multirow{2}{*}{\multicolumn{2}{|c|}{ Swartky and Stayman (1962) }} & $\cdots$ & $\cdots$ & $\mathbf{M}$ & 7 yrs & Yes & None & Laparotomy & Resection \\
\hline & & & & $\underset{\mathbf{M}}{\mathbf{F}}$ & $\begin{array}{l}3 \text { yrs } \\
5 \text { yrs }\end{array}$ & $\begin{array}{l}\text { No } \\
\text { No }\end{array}$ & $\begin{array}{l}\text { Massive } \\
\text { Minimal }\end{array}$ & $\begin{array}{l}\text { Resection } \\
\text { Laparotomy } \\
\text { and biopsy }\end{array}$ & - \\
\hline Freeman and Beck (1962) & $\cdots$ & $\cdots$ & $\cdots$ & $\mathbf{M}$ & $21 \mathrm{mths}$ & No & Moderate & $\begin{array}{l}\text { Laparotomy } \\
\text { and biopsy }\end{array}$ & - \\
\hline Present case .. & . & . & . & $\mathbf{M}$ & $7 \mathrm{mths}$ & Yes & Minima! & Reduction & Resection \\
\hline
\end{tabular}

the ileum (Clubbe, 1921; Gross, 1953). This may be related to the anatomy of the ileocaecal valve and to the distribution of lymphoid tissue at this site. Perrin and Lindsay (1921-1922) showed that the ileocaecal valve had a somewhat conical shape in infancy, and projected for nearly $1 \mathrm{~cm}$. into the caecum. Peyer's patches in the small intestine are confined to the anti-mesenteric border of the bowel except in the ileocaecal region where several patches are found encircling the ileocaecal valve (Fig. 3).

The macroscopic appearance of the lesions at the ileocaecal valve suggests a hyperplasia of the Peyer's patches at this site. In an overweight child with prominent lymphoid tissue a minor degree of irritation might produce sufficient lymphoid hyperplasia to cause a partial intestinal obstruction at the ileocaecal valve. Peristaltic activity would then drag on the enlarged patches, cause further irritation and local oedema, and produce a papillary appearance of the Peyer's patches at the ileocaecal valve.

This seems a reasonable explanation for the present case, and for most if not all of the cases listed in the Table. Fortunately the prognosis is good and none of these patients appears to have had further trouble after surgical resection had been carried out.

\section{Summary}

This report illustrates a case of recurrent acute intussusception due to papillary lymphoid hyper- plasia at the ileocaecal valve in a 7-month-old male infant. Reference is made to similar cases reported in the literature. The lesion appears to be due to the effects of peristalsis on enlarged Peyer's patches surrounding the ileocaecal valve.

We are grateful to Mr. David Levi for permission to publish clinical details of the patient under his care.

\section{REFERENCES}

Clubbe. C. P. B. (1921). The Diagnosis and Treatment of Intussusception. 2nd ed. Oxford University Press, London.

Cooke $D$. C and Lewis, E C (1960). A thirty-year survey of acute intussusce-tion in childhood: 269 cases. Lancet, 2. 1359.

Czerney, A. (1907). Zur Kenntnis der exsudativen Diathese. Mschr. Kinderheilk.. 6, 1.

Dennis, C. (1947). Resection and orimary anastomosis in treatment of gangrenous or non-reducible intussusce $t$ tions in children A safe. simple, one-layer silk anastomosis. Ann. Surg., 126, 788.

Freeman. F. J. and Beck, W. C. (1962). Lymphoid hy ierplasia of the ileum as a surgical entity. Guthrie Clin. Bull. (Sayre), the ileum 141 .

Gross. R. E. (1053). The Surgery of Infancy and Childhood. Saunders, Philadelfhia and London.

Morrison, B. and Court, D. (1948). Acute intussusception in childhood. Brit. med. J., 1, 776.

O'Sullivan, W. D. and Child, C. G. (1951). Ileocecal intussusception caused by lymphoid hyferplasia. J. Pediat., 38, 320.

Perrin. W. S. and Lindsay, E. C. (1921-1922). Intussusception: a monograph based on 400 cases. Brit. J. Surg., 9, 46.

Roviralta, E. and Roca De Vinals. F. (1958). Invaginacion intestinal aguda en un hetante por hiperplasia linfoidea no tumoral. aguda en un lactante por hiperplasia linfoid
Reseccion. Curacion. Rev clín. esp., 71, 45.

Sarason, E. L., Prior, J. T. and Prowda, R. L. (1955). Recurrent intussusception associated with hypertrophy of Peyer's patches. New Engl.J. Med., 253, 905.

Stout, A. P. (1927). Isolated lymchoid hyperplasia in the cecum and aprendix of children. Amer. J. Dis. Child., 34, 797.

Swartley, R. N. and Stayman J. W. (1962). Lymphoid hyperplasia of the intestinal tract requiring surgical intervention. Ann. Surg., $155,238$.

Wakeley, C. P. G. and Atkinson, F. R. B. (1938). Acute intussusception in children. Brit. J. Child. Dis., 35, 241

Walton, A. J. (1911). Intussusception. Practitioner. 87, 186. 